\title{
LAW ENFORCEMENT TO OFFENDERS' RIGHTS BASED ON CONTEMPT OF COURT
}

\author{
Ibnu Subarkah, Lukman Hakim, Anwar C \\ Law Faculty of Widyagama University, Malang \\ Email: bn_spirit@yahoo.com; lukman_cri@yahoo.co.id; \\ anwar_cengkeng@yahoo.co,id
}

\begin{abstract}
In legal field, especially related to judicial field of judiciary, efforts to reform criminal law and to overcome justice and certainty are done incessantly which means that law enforcement efforts need to be effected. Some situations and conditions may reduce judicial image if the law enforcement is lacking or not being noticed at all. The existence of cases through legal research and opinion of legal practitioners have varied the existence of judiciary images. Therefore, this research is specifically aimed to find out, describe, and at the same time analyze the rights of defendants (offenders of rights) based on contempt of court. The method used in this study is qualitative research prioritizing quality and primary and secondary data types. The primary data are taken empirically from the field and the secondary data are taken from literature study, determination of respondents by purposive sampling. The results show that, in practice, the rights of defendants are protected in accordance to the applicable provisions as well as the contempt of court issue. Due to the subjective perception of community in the course of trial, it is essentially needed to immediately draw up the Contempt of Court Law.
\end{abstract}

Keywords: Law Enforcement, Offenders' Rights, Contempt of Court, Penal Reform

\section{A. INTRODUCTION}

Indonesia is a constitutional state, as mentioned in Article 1 paragraph (3) (The Constitutional Court of the Republic of Indonesia, 2010: 5), whose characteristic is providing guarantee and protection of Human Rights. The independent courts should be free from any interference of any party, and the creation of legality in all its forms. Obviously, this issue is in the field of judicial authority, and it is said by $\mathbf{J}$ Margarita Cheshmedzhieva (2014: 206) that governmental affairs in this matter of judicial authority are a matter of concern, "In the implementation of the performance according to the signal, the adverseeffects on those

552 Yustisia Vol. 6 No. 3 (September - December 2017) ～Law Enforcement To Offenders ....

(C) 2017; This is an Open Access Research distributed under the terms of the Creative Commons Attribution Licensee (https://creativecommons.org/licenses/by/4.0), which permits unrestricted use, distribution, and reproduction in any medium, provided the original work is properly cited. 
affected caused by the illegal or inappropriate actions, are removed. Ifthis is not possible, the persons affected are satisfied in another legal way, recoveringtheir violated rights. With the execution of the judgment the proceedings under the specific signalfinally end. Thus, the goal of the signal as a means of supervising the activity of theadministration and citizens' participation in governance is achieved". Therefore, sociologically, Lawrence M. Freidman (1975: 16) suggests that legal system is in fact a complex form of organization in which structures, substances, and cultures react with each other. The function of this legal system is to divide and serve as a means of allocating values in accordance with the rights of the people, means of dispute settlement, controlling society, as well as means of renewal:

"A legal system in actual operation is a complex organism in which structure, substance, and culture interact. The function of the legal system are to distribute and maintain an allocation of values that society feel to be rights, the settlement of dispute; social control; as an instrument of orderly change of social engineering".

In the case of and experienced by justice seekers from the groups of low class classification who are economically and naturally weak (ie, girls, elderly) will become a problem in law enforcement. As an examination on the impact of mental illness to a low level crime was put forward by Michael Ostermann and Jason Matejkowski (2014: 23):

"The prevention of such low-level crimes and the reductions in the relatively small costs to society resulting from such crimes indicate that investments in recidivism reduction programs aimed at individuals who commit such crimes would reach a point of diminishing returns much more quickly than if efforts were to target those individuals who are more likely to commit felonies, violent crimes, and crimes against people (i.e., crimes that are higher cost to society".

The increase of quality (criminals and the crimes) and the quantity of crime can be an indication to the ineffectiveness of penal and non-penal measures, both treatment of society, and treatment of offenders and prevention of crime. The condition of nation who is economically unstable, unmeasured development performance, and the strengthening of funds in political field are contributing factors to the failure of penal and 
non-penal prevention (Barda Nawawi Arief, 1996: 10). It affects the demands by society to obtain satisfaction in seeking justice, especially aimed at the demands of justice bureaucracy of the Court administrator, which starts on the satisfaction of justice as part of seeking a fair and just law (due process of law). In addition, in the process of law enforcement when a law is enacted, there is a formation of negative culture of wrong mindset on the justice seekers and the community, and this will have a significant effect on law enforcement itself, with the thought that if desiring justice rather than victory, then the process of handling a case will be protected, and, if expecting victory rather than justice, the process of handling case will be immediate and quick. The degradation of judicial image (Abdul Wahid, et al, 2009: 185), becomes great, if correctional action is not immediately taken, especially in the enforcement of criminal law. The court organization in each region is obviously faced with problems, on the one hand can be victim, while on the other hand can also be considered by justice seekers as the offenders, where the justice seekers community is the victim of an organization. (Russell R. Dynes and E.I. Quarantelli, 1974: 68) very few studies have taken specific aspects of organization in to account in understanding the victim-offenders relationship, means that an organization also possess social responsibility in its decision.... social responsibility has been writen in to corporate behaviour.

Therefore, if the effort of healing the community and the violators will no longer be effective, whereas the satisfaction of justice becomes the main part, the hope that will arise is the formation of law enforcement efforts along with the existing facilities and bureaucracy, for truth and justice to be no longer a dream and fear for the justice seekers from the low class and those troubled before the law can seek and pursue the satisfaction of justice. In this connection, the thought that the satisfaction of justice can be pursued even though the sky will collapse is no longer as a figment. put forward the idea, that the re-evaluation through the re- 
selection of active Supreme Judges is a form of distrust by the Judicial Commission against the highest judicial institutions in Indonesia. It further argues that there are some judicial interference actions that are qualified by a criminal justice which is contrary to the Criminal Code, namely Sub Judice Rule, that is an attempt to influence the outcome of a judicial examination; Disobeying court order; that is not obeying the judicial order; Obstructing justice, that is making an obstruction of justice; Misbehaving in court, that is not well behave in court (Omar Seno Adji and Indriyanto Seno Adji 2007: 95). In relation to the criminal justice system, points out, "... So, it is recommended that justice should be done in 'once for all' in the first level only. Internally controlled and closed from public view, amid the decline of professional ethics, collusion at the appellate court and above it will be easy to take place, which will only augment public's suspicion on what goes on behind the doors of the court. " he attributed that in the current criminal justice system, it has shown an anomalous condition (SoetandyoWignjosoebroto, 2009: 9).

The characteristics of the judiciary developed in Indonesia, as well as other countries that adheres to the civil law tradition, in the context of criminal justice proceedings, adhere to non adversary systems, although they do not escape the adversary system as stipulated in the United States Constitution. Herbert L Packer has described 2 (two) theories of Justice in the scope of criminal justice system, namely "crime control model and due process model, where the crime control model emphasizes the importance of the existence of power and the use of power against every crime and perpetrator, while due process model which is based on the presumption of innocence as the basis of the value of the judicial system that aims to protect someone who is truly innocent and charge those who are truly guilty (Romli Atmasasmita, 1996: 108-110).

Some attention to the rights of the defendants (offender's rights) and the explanation above, given the theory of justice in the judicial system between limiting and using the power maximally by law enforcement 
officers, especially judges, where the level or degree of problems is so high, until there is a thought to reform the judicial system, the faded judicial image, the logical consequences based on the juridical, sociological, and philosophical conditions, occurred acts that considered as undermining the authority of the court, called contempt of court. (Law Number 14 of 1985). The perpetrators need to be protected by offender's rights, which are currently contained in the principles and norms of Criminal Procedure Code, have not been re-evaluated, to be reoriented, especially those based on contempt of court, and judges also need to be protected, from the families of the victims or perpetrators or trial visitors. Therefore, the author presents the issue of law enforcement of defendant's rights based on contempt of court, then its relationship with the reform of penal law (penal reform). (Barda Nawawi Arief, 2007, 31-32) by presenting approaches. Description of contempt of court cases, where the perpetrator of the defendant no longer respects the hearing of the trial where "the non-active prosecutor from Cibinong District Attorney who was accused of bribery at the Corruption Court of Bandung, Sistoyo, was slashed by a visitor after the trial on Wednesday (29/2). It shows thuggery still happening. Yani believes that Indonesia has the right to have a regulation on contempt of court, not in its own rules, such as law, but it is included in the Criminal Code or Criminal procedural Code. "(Online law, February 29, 2012, accessed on May 18, 2017 at 02.30).

The specific purpose of this research is to find out and describe and analyze the rights of defendants (offender's rights) based on contempt of court. From some rights of defendants, there are rights that have a tendency related to contempt of court, then how it relates to law enforcement through policy approaches and values to reform of penal law (penal reform). The urgency of this research is as described above, the unclearness and the problem caused by contempt of court, whereas the Criminal Code has regulated but as colonial's relics. On the other hand, the desire of judicative field to immediately make legal draft on contempt 
of court with a severe criminal sanction, including changes in Criminal Procedure Code. Some circles of other law enforcement agencies disagree and it is also important to provide input to reform criminal law in Indonesia. The author offers a model based on research, inventorying and evaluating, reorienting values which previously were never undertaken by academics and other jurists, namely the rights of the defendant from some instances of exemplary, contempt of court based tendencies, analyzed by the concept of criminal renewal law, known as 3 approaches: social policy approaches, criminal policies (crime prevention), and law enforcement policies, and value approaches. Then the targets of the findings are in the form of clauses related to social policy, criminal policy, (in this case is crime prevention policy), law enforcement policy in the form of sanctions for contempt of court actors (which still refers to the colonial legacy book, the Criminal Code ), then it needs a new formula or formulation of clauses is required, which according to the author's opinion, the amendment to Law Number 48 Of 2004 on Judicial Authority where Article 3 paragraph (2) said that the interference of judicial matters outside the Judicial Authority is prohibited; (3) subject to punishment as referred to in paragraph (2), in accordance with existing legislation. The last sentence was changed with ..... "according to this law". It means that the proposed legal Draft becomes a part of Special Criminal Law, in the meaning of "not a crime but bear criminal sanction" legislation as a form of Law outside of the Criminal Code. (Azis Syamsudin, 2011: 8).

\section{B. PROBLEM STATEMENT}

Based on the introduction, Author will discuss how law enforcement to offenders' rights based on contempt of court is?

\section{RESEARCH METHOD}

This study is a descriptive study (Masri Singarimbun, 1989: 4-5) which contains research intent for careful measurement of certain social 
and cultural phenomena by developing concepts and collecting facts but not testing hypotheses. In the preparation of policies used patterns of preparation with certain stages. (William N. Dunn, 1998: 25) Where researchers describe through qualitative research, is an empirical legal research in the Court, defined as research whose data obtained from primary data, means the data were obtained by way of plunging into the field or direct data with the selection of samples by purposive sampling or purposive samples, deliberately taking into account the intent and purpose of the study. The selection of respondents was done by taking the subject, not based on strata, or random, but based on a particular purpose. As for the informant / respondent is the Judges at Malang District Court, that with the location of this research is in East Java jurisdiction of the High Court where the mobility rate is high, and several years before, the author conducted intensive research on the Court. The data type is Primary data, as the main data in this study, obtained directly from the above informants, and the secondary data, as a documentative supplementary data, through literature study on the literature that suits the informants and the above problems. The technique of collecting data was done by interview (interview), not structured. (Ronny Hanitijo Soemitro, 1988: 61). The data analysis used in this research is descriptive qualitative method which obey the procedure of data reduction, data collection, data presentation, and drawing conclusion / formulation, where the analysis of problem under this study is by describing or narrating the existence of subject and object of research based on facts without using numbers, but prioritize the quality of the existing data.

\section{RESEARCH RESULT AND DISCUSSION}

\section{D.1. Law Enforcement On The Rights Of The Accused (Offender's Rights)}

Normatively, the intended state of law is contained in Law Number 8 of 1981 on the Criminal Procedure Code, which behind this regulation is 
sustained by 10 (ten) principles to guarantee the rights of the accused / defendant, as follows:

"Equal treatment before the law, without any discrimination: Presumption of innocence: Right to get compensation (compensation) and rehabilitation: Right to legal aid: Right of presence of defendant before court, free and quick and simple judiciary Public court of law: Violations of the rights of the citizen (arrest, detention, search and seizure) must be based on the law and done by written order; The right of a suspect to be informed of his suspicion and prosecution of him, and the duty of the court to control the execution of his verdict." (Op, cit, Romli Atmasasmita, 41).

Those 10 (ten) principles mentioned above put themselves in an important position, because as a basis that exists in a norm or rule in Law Number 8 of 1981 on Criminal Procedure Code. The norm or rule can be known, namely "Article 50 paragraph (3) of the Criminal Procedure Code stipulates that:" The defendant is entitled to be immediately tried by the court; and other rights under Article 51 paragraph (2) of Criminal Procedure Code; Article 52 of Criminal Procedure Code; Article 53 paragraph (1) of Criminal Procedure Code; Article 54 of the Criminal Procedure Code, Law Article 55 of Criminal Procedure Code, Article 56 paragraph (2) of Criminal Procedure Code, Article 58 of Criminal Procedure Code; Article 60 of Criminal Procedure Code Article 62 paragraph (1) of Criminal Procedure Code, Article 62 paragraph (2) of Criminal Procedure Code, Article 64 of Criminal Procedure Code, Article 65 of Criminal Procedure Code; Article 66 of Criminal Procedure Code; Article 68 of Criminal Procedure Code."

The above normative provision is a juridical basis to the exercise of the rights of the suspect / defendant to be enforced. However, in practice, observed from its forms, it often occurs violations to the suspect / defendant's rights that can be categorized in two parts, namely "administrative and procedural violations of investigation and inquisition, and violation to the personal (soul \& body). (CSA Teddy Lesmana, www.ilnews.co.cc, April 18, 2016). Given the above violations it affects the issue of judicial image, and this is further confirmed by I Gede Artha, 
(2012) some facts of a case had injured the sense of community justice in the form of some judges' verdicts by releasing the defendants free. The situation triggered and invited the reaction of wider community, the pros and cons, even controversy. Public accusations against the image of judiciary with negative connotations are increasingly prevalent and often end up with harassment and humiliation of court authority or credibility of judges. In the language of judicial practice law there has been contempt of court action.

Looking at contempt of court case, the Judge of Malang District Court said that the number of judges is limited, but the number of cases is so great, as compared with the institution of the Attorney Office (author research, May 15, 2016). Subsequently submitted by Prosecutor at Malang District Prosecutor's Office, that "when the right to appeal, a copy or a quote is not immediately submitted to the Public Prosecutor that handling the case, then the public prosecutor estimates to make additional appeal memorial" (author research, May 26, 2016).

Enforcement of rights based on rule is a must. While the protection for it is scattered / dispersed, which results in the importance of drawing up a legislation. It is practically necessary to balance the legal protection of justice seekers with judges and courts, aimed at "subjective perceptions of the outcome of trial when the judge handed down the verdict. Judges at Malang District Court". When there is a question of whether there is a relation between the rights of the defendant and the contempt of court. (author research, September 2017). In the context of law enforcement, a verdict that has been decided by judge does not necessarily meet the standards of satisfaction by justice seeker. Therefore, it is natural that legal certainty in the form of supervision to the judge is deemed necessary to be effected. The purpose of prevailing and the functioning of law in this matter is not achieved. (Fatkurohman, et al, 2012: 31) 


\section{D.2. Contempt Of Court As Base.}

Ideas and thoughts, and factually based on existing legal facts, both nationally and internationally, issues of judicial action (court of law) have existed for a long time, in Anglos Saxon State, especially in the United Kingdom. The Contempt of Court is a well known term since the 13th century on the strict Anglo-Saxon States with an adversary system, especially the British. In this system is also known the battle of gladiator between lawyers and public prosecutors who show freedom in the trial, so that the judge who is passive requires a shield for protection. Contempt of court itself is defined as a consisting act or omission substantially disrupting or obstructing the judicial process in a particular case, which includes 2 (two) things; contempt of facie and contempt ex facie. (Omar Seno Adji, 2007: 104). Especially in the State of Indonesia, the above contempt of court has been scattered according to the articles of Criminal Code, for example Article 217 of the Criminal Code which threatens criminal if "noisy in court", Article 315 of the Criminal Code, which threatens criminal if committed insults with a speech, and so on.

Given that a reform of penal law or penal reform indicating excavation on religious and customary values, as well as stripping of the colonial nature, (Barda Nawawi Arief, 2011: 3). In line with this, Soerjono Soekanto (2009: 16) proposed that law is a link of new values, that is, from abstract conceptions in human beings about what is considered good (so it should be adhered or obeyed) and what is considered bad (so it should be avoided). Therefore the issue of reform of criminal law relates to the change of values in society.

\section{D.3. Reformation Of Criminal Law}

In addition to comparative study and harmonization from the traditional and religious law system, national criminal law reform is also required to conduct comparative studies with the development of ideas and cutting-edge ideas/theories in criminal law and in global/international 
agreements, which requires balance among others prevention of crime, treatment of offenders and treatment of society, and other equilibrium (Barda Nawawi Arief, 2011: 3).

It means that in countermeasures which mean penal (penal application) and non penal (cultivate / cure the perpetrators and damages in society) is not enough if the intervention of justice affairs only prevent the behavior of judges but also prevent the behavior of those who influence the judge, or other societies, which means that Article 3 paragraph (2) and paragraph (3) of Law Number 48 of 2009 on Judicial Authority, not only contains criminal penalties as an element of criminal acts, but also contain the provisions of norms and need to be reformed, reoriented, and reevaluated. In the context of reform of criminal law, it can be added by conducting studies on the angle of policy approach which is; a) as part of social policy, means part of the effort to overcome social problems (including humanitarian problems) in order to achieve / support the national goal of community welfare; b) as part of a criminal policy, means part of the protection effort of the community (especially crime prevention); c) as part of law enforcement policy, means part of the effort to renew legal substance in order to make the law enforcement more effective. Viewed from the point of view of values, the renewal of the criminal law is an attempt to review and re-orientate and re-evaluate the socio-political, socio-philosophical, and socio-cultural values that underlie and contribute to the normative and substantive content of ideal law.

In a research result, it is known that the form of interference of judicial matters outside the judiciary can be in the form of fine or coarse, which can then be described as the effect of the quality of crime and the quality of the perpetrator contributing to the interference. The act of interference of judicial matters outside the judicial authority may occur by means of media. The case of BG against BW, if observed, we can sense the deep influence of the media, which leads the society's view to the existence of crime and offense. This is indeed has no punishment for it. 
Furthermore, according to the author's opinion, the use of the word intervention is a legal language as textually determined in the Law Number 48 Of 2009 of Judicial Authority, Article 3 Paragraph (2), which states that the interference of judicial matters beyond the judicial authority is prohibited ... etc., and the definitions contained in Interrupting Court Proceedings are annulled the words or acts that obstruct or interfere in court proceedings can be punished for criminal contempt, and the words or deeds are spoken or performed in the courtroom (Ibn Subarkah, Report of Results Research, August 2012). In paragraph (3) as regulated under Article 3, Law Number 48 of 2009 on Judicial Authority, determines that interference in judicial matters outside the judicial authority is prohibited and may be punished, according to their respective laws and regulations. General Explanation Item 1, Law Number 5 of 2004 on the Supreme Court states "Independent judicial authority is one of the important principles for Indonesia as a state law. This principle requires judicial authority to be free from interference by any party and in any form so that in carrying out its duties and obligations, there is a guarantee of impartiality of judicial authority except on law and justice. "(State Gazette of the Republic of Indonesia of 2004 Number 9:14)

In the United Kingdom, according to Muladi, the existence of juridical restriction that is the contempt of court. (Muladi, et al., 1999: 89) is an insult to the judiciary as a violation of court order. In Indonesia this has not been confirmed juridically, which one the regulation of norms as well as the threat of criminal. This, if regulated separately in the Draft of Law outside the Criminal Code, the interpretation of Article 103 of the Criminal Code, with the pattern of irregularities and special provisions, then obviously to the guarantee and protection of Human Rights, the guarantee of independent judiciary in the sense of independence judiciary, the authority of the judiciary that is not halfhearted of its law enforcement, the judicial power containing the pretensions of abuse of power in the one roof system, which in the future can be minimized, and can meet the 
criteria of the intended state of law. (Abdul Wahid, et al, 2005: 279) In any criminal act in Indonesia, this issue of law enforcement is important, as stated by Muhammad Rustamin and Syafrudin Yudho Wibowo (2010: 28), that:

"The efforts made to make the law, both in narrow formal meanings and wide material meanings, to be a code of conduct in every legal act, either by the concerned legal subjects or by the official enforcement apparatus which duty and authority is granted by law, to ensure the functioning of legal norms prevailing in the life of society and state."

There is a study characterized by public dissatisfaction with the performance of the judiciary and its apparatus. (Ahmad Mujahidin, 2007: 209) The security of judges when examining a case is important. For this matter of interference depends on the party in how they react to, and must be careful when trying the case. The form of interference may be subtle (when the judge has once heard a case on the cutting of a plant by a member of sector military unit) and in a rude/blatant form; the existence of interference in the affairs of the judiciary arises as a result of the impasse of the parties to the judicial process that put forward the principle of legal certainty but has not felt the benefit and justice of the parties and lack of understanding for the parties. (Ibn Subarkah, et al, 2015: 46) The importance of administrative technical reform in judiciary process is in line with the demand for improved judicial performance, because the technical implementation of the judiciary is not supported by adequate technological, judicial, and human resources equipment. Inadequate technological devices such as computers in a judiciary will result in slow preparation of court decisions. Conditions such as scarcity of work tools and other work support facilities even occur in Jakarta, not just small towns outside Java. (loc. Cit.) According to the author's opinion, the application of Article 3 paragraph (2) and (3) in the Law on Judicial Authority is not trapped; first, as a norm that its application is at the desire of law enforcer; and second, norms that violate the rights of public in expressing opinions, which still firmly heed that the wrongness of one is 
determined by judicial authority which has been through the process of fair and just trial (due process law) (Ibn Subarkah, 2010: 49). The meaning of interference in order to get the judiciary and the courts free from the influence of any party, especially the press, said Bagir Manan, that according to him, as a press criticism on the courts and the judiciary (Bagir Manan, 2011, 68) which serves to support the implementation of Laws and Regulations of Supreme Court on public information disclosure, sustaining the implementation of the constitutional rights of every person (public) to obtain information (the rights of information) as regulated in the 1945 Constitution, Article 28F that provides an opportunity for public to assess the implementation of judicial functions as a source for the judicial body to make corrections, take action, or make decision into the circumstances or events that published by the press; to encourage the court to perform its functions efficiently and effectively; to avoid various congestion obstacles in the judicial process, encourage prudence in matters and decide cases, encourage court efforts to improve integrity and clean environment of judiciary, far from abuse of power or miscarriage in judging and deciding cases; protect and assist the courts, when facing unfavorable pressure from power, the public, or of a particular interest; exercise social oversight by disclosing to the public unlawful or suspected unfair actions occurring within the court or judiciary; press information is a means of dialogue between the public and the courts. In addition to the issue of press in his interference as stated above, Anwar Usman (Promotion Doktor Pasca.ugm.ac.id/id/promotion_view.php?dc_id=82, admin at [31/01/2011, 09:47:46]) argued that the forms of intervention or interruption on the independence of Judicial Authority is motivated by the phenomenon of widespread intervention on judicial freedom and independence of judicial power. 


\section{E. CLOSING}

\section{E.1. Conclusion}

From the above explanation and discussion, it can be concluded as follows:

1. On the fulfillment of offender's rights, the trial is entirely dependent upon the subjective perception of society. A national example, Obstruction of Justice, is one form of contempt of court, which is said to be the subject of discussion for the existence whether senator's questionnaire right to the Commission for Eradication of Corruption is an obstruction of justice. This is one form of public perception which judge is subjective, which is then examined in the constitutional aspect;

2. Basically the rights of defendants are fulfilled in court, in a law enforcement efforts based on the Criminal Procedure Code, which will provide a free expectation and desire from law enforcement to develop Contempt of Court Law, aimed at protecting judges and courts.

\section{E.2. Suggestion}

Based on the above explanation, the following suggestions may be raised:

1. In order for judges and courts to always pay attention to the rights of defendants in court, although subjective perceptions still exist in criminal decisions;

2. If national contempt of court is to be avoided, the enforcement of law against the rights of the defendant can meet the objectives of a correct and fair decision.

\section{BIBLIOGRAPHY:}

\section{Books:}

Arief, Barda Nawawi, 1996, Bunga Rampai Kebijakan Hukum Pidana (Civil Law Policy Bonds), Bandung: PT. Citra Adtiya Bakti 
Arief, Barda Nawawi, 2011, Pembaharuan Hukum Pidana, Dalam perspektif Kajian Perbandingan (Criminal Law, In The Perspective of The Comparative Review), Bandung: PT Citra Adtya Bakti

Artha, I Gede, 2012, Kebijakan Formulatif Upaya Hukum Terhadap Putusan Bebas Bagi Penuntut Umum, desertasi (Formulative Policy of Legal Efforts Against Free Decision for The Prosecutor), Malang: Fakultas Hukum, Universitas Brawijaya

Atmasasmita, Romli, 1996, Sistem Peradilan Pidana, Perspektif Eksistensialisme dan Abolisianisme, Cetakan ke II (Criminal Justice System, Existentialism Perspective and Abolishim), Jakarta: Penerbit Putra A. Bardin

Dunn, William N, 1998, terjemahan, Pengantar Analisis Kebijakan Publik (Introduction to the Public Policy Analysis), edisi kedua. Yogyakarta: Gajah Mada University Press

Hutchinson, Terry, 2002, Researching and Writing in Law, First Edition, Lawbook Co. Sydney: Karolina Kocalevski Publisher

M. Friedman, Lawrence, 1975, Legal System, A Social Scence Perspective, New York: Russel Sage Foundation

Marzuki, Peter Mahmud, 2011, Penelitian Hukum (Legal Research), Jakarta: Kencana Prenada Media

Mujahidin, Achmad, 2007, Peradilan Satu Atap di Indonesia (One Roof Tribunal In Indonesia), Jakarta: PT Refika Aditama

Muladi, dkk, 1999, Pertanggungjawaban Korporasi Dalam Hukum Pidana (Corporate Accountability in Criminal Law), Bandung: Sekolah Tinggi Hukum

R. Dynes, Russel, at.al, 1974, Organization as Victim in Mass Civil Disturbances, Victimology, edited by Israel Drapkin and Viano. London. Lexington Books D.C. Health and Company Lexington, Massachusetttes

Seno Adji, Indriyanto, 2007, PERPU Komisi Yudisial : "Intervensi atau Pembaharuan MA", dalam Peradilan Bebas dan Contempy Of Court. Jakarta. Diadit Media

Singarimbun, Masri dan Sofyan Effendi, 1989, Metode Penelitian Survey (Survey Research Methods), Jakarta: LP3ES

Soekanto, SoerjoNumber, 1979, Mengenal Sosiologi Hukum (Understanding to the Sociology of Law), Bandung: Alumni

Soemitro, Ronny Hanitijo,1988, Metode Penelitian Hukum dan Yurimetri (Legal Research Methods and Jurymetry), Jakarta: Ghalia Indonesia

Subagyo, P. Joko, 1997, Metode Penelitian : dalam Teori dan Praktek (Research Methods: Theory and Practice), Jakarta: Rineka Cipta

Syamsuddin, Aziz, 2011, Tindak Pidana Khusus (Special Crime), Anis Fuadi (penyunting), Ed. 1, Cet. 2, Jakarta: Sinar Grafika,

Wahid, Abdul, dkk, 2009, Etika Profesi Hukum, Rekonstruksi Citra Peradilan di Indonesia, Edisi I, Cet. I (Ethics of Legal Profession, Reconstruction of Judicial Image In Indonesia), Malang: Bayu Media Publishing 


\section{Regulations:}

The 1945 Constitution of The Republic of Indonesia

Law Number 8 of 2011 on The Constitutional Court, Indonesian Gazzette Number 70 of 2011

Law Number 48 of 2009 on Yudicative Power, State Gazzette of The Republic of Indonesia Number 157 of 2009

Law Number 14 of 1985 on The Supreme Court, State Gazzette of The Republic of Indonesia Number 73 of 1985

.Law Number 8 of 1981 on The Criminal Procedure Law, State Gazzette of The Republic of Indonesia Number 9 of 1981

\section{Journals:}

Cheshmedzhieva, JMargarita, 2014. Civil Signals - A Major Democratic Method against Corruption Practices in Contemporary Society Journal of Law and Criminal Justice December 2014, Vol. 2, No. 2, ISSN: 2374-2674 (Print), 2374-2682 (Online) Copyright (c) The Author(s). 2014. All Rights Reserved. Published by American Research Institute for Policy DevelopmentDOI: 10.15640/jlcj.v2n2a12

Fatkhurohman, dkk. 2012. Efektivitas Penyelesaian Pembatalan Peraturan Daerah Melalui Metode Keberatan di Mahkamah Agung oleh Pemerintah Daerah Kota/Kabupaten, Jurnal Hukum Yustisia, Terakreditasi, Edisi 84, Tahun XXII, September-Desember 2012. Surakarta. FH UNS

Ostermann, Michael dan Jason Matejkowski. 2014. Estimating the impact of mental illness on costs of crimes A Matched Samples Comparison, Criminal Justice and Behavior, Vol. 41, No. 1

Rustamadji, Muhammad, dkk. 2010. Pengaruh Penegakan Hukum Undangundang Informasi dan Transaksi Elektronik terhadap Upaya Pemblokiran Situs Porno pada penyedia Jasa Internet di Surakarta, Jurnal Hukum Yustisia, Terakreditas, Edisi 80, Tahun XXI, Mei-Agustus 2010, Surakarta. FH UNS

Subarkah, Ibnu. 2009. Upaya Penanggulangan Terhadap Recidive dengan pelaku Anak di Wilayah Hukum Pengadilan Negeri Kabupaten Malang, Jurnal Hukum Yustisia, Terakreditasi, Edisi 77, Tahun XX, Mei-Agustus 2009, Surakarta. FH UNS

Subarkah, Ibnu. 2010 Elastisitas bagi Kemandirian Peradilan, Majalah Varia peradilan Tahun XXV No. 295 Juni 2010. Jakarta. IKAHI-Mahkamah Agung

Subarkah, Ibnu. 2011. Pemidanaan Campur Tangan Urusan Peradilan dalam Persepektif Organisasi dan Kekuasaan Kehakiman, Majalah Varian Peradilan Tahun XXVII No. 302 Januari 2011, Jakarta: IKAHI-Mahkamah Agung

Subarkah, Ibnu. 2012. Studi Terhadap Perlindungan Anak Dari Buruh Migran/TKI ke lauar Nageri di Daerah, Jrunal Konstitusi PKK Fakultas Syariah IAIN Antasari Kerjasama dengan Mahkamah Konstitusi RI, Vol. 1 No. 1 November 2012. Kalimantan. Fakultas Syariah 
Subarkah, Ibnu dan Lukman Hakim. 2015. Penanggulangan Campur Tangan Urusan Peradilan di Luar Kekuasaan Kehakiman, Jurnal Hukum Yustisia, Edisi 92, Tahun XXIV, Mei-Agustus 2015. Surakarta. FH UNS-Surakarta

\section{Internet:}

Hukum online.com,Pembacokan Terdakwa di Pengadilan Dikategorikan Contempt of Court, Rabu 29 Februari 2012, diakses 18 Mei pukul 02.30.

www.ilinews.co.cc. posting 3 April 2011, diakses, 18 April 2016, pukul 11.00 WIB

Pasca.ugm.ac.id/id/promotion_view.php?dc_id=82, 2011.Bentuk-bentuk Intervensi Terhadap Independensi Kekuasaan Kehakiman: Relevansinya bagi Penegakan Hukum dan Keadilan di Indonesia (Penelitian Disertasi), Pascasarjana UGM submitted by: admin at [31/01/2011, 09:47:46]

Diposkan oleh Dialektika Hukum DI 06:19, Jum'at, 20 Februari 2009, Ke arah Reformasi Sistem Peradilan Indonesia, sebuah makalah ringkas yang diceramahkan dan didiskusikan dalam acara Seminar "Refoemasi Sistem Peradilan di Indonesia" yang diselenggarakan oleh Badan Pembinaan Hukum Nasional Departemen Hukum dan Ham RI di Palembang, 3-4 April 2007

\section{Research Report:}

Ibnu Subarkah, dkk.2012. Membangun Kebijakan Formulasi Pemidanaan Campur Tangan urusan Peradilan di Luar Kekuasaan Kehakiman (Studi di Wilayah Hukum Pengadilan Negeri Kepanjen Kabupaten Malang, Jawa Timur), Laporan Penelitian, Jakarta: Kemendiknas 